\title{
INCREASE THE QUALITY AND REDUCE THE COSTS OF ENVIRONMENTAL MANAGEMENT THROUGH ACCREDITATION AND CERTIFICATION
}

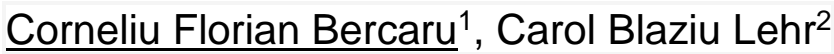

${ }^{1}$ CERTIND, 27-29 George Enescu st, Bucharest 1, Romania, corneliubercaru@yahoo.com

${ }^{2}$ National Research and Development Institute for Industrial Ecology - ECOIND, 7173 Drumul Podu Dâmboviței St., 060652, Bucharest, Romania

\begin{abstract}
The pressure of human activity on the environment is growing. Industrial activity, transport produce pollutants that degrade the environment with long-term devastating effects on humanity. The establishment and implementation of the legislative aims to reduce / balance the effects of pollution. Implementation of appropriate solutions in combating pollution is based on:

reliable information on the environmental impact agents;

implementation to the economic agents of monitoring system / rapid response to the detection of trends on emissions growth

1. The main information on the polluting agents are laboratory tests; according to these information resources are allocated. The degree of confidence in the information depends on the internal / external system of checks of the laboratory. Accreditation by an internationally recognized body gives maximum confidence in quality tests conducted by a laboratory.

2. Economic agents are obliged by law to maintain control of environmental issues. Confidence in implementing an effective environmental monitoring system is the result of environmental factors on reducing / maintaining emissions within legal boundaries. Environmental certification system implemented by the economic agents by a recognized body provides confidence in the application of best prevention solutions.

Resources needed on accreditation of laboratories / certification systems implemented by economic agents are preventive actions, representing about $30 \%$ of the resources allocated to corrective actions (actions compulsory environmental incidents).
\end{abstract}

Keywords: accreditation, certification, pollution, resources

\section{INTRODUCTION}

Any human activity is inconceivable outside environment. Between human activity and nature take place a permanent exchange that affect the ecological balance and cause life conditions.

Increasing population implies growth of resource needs (food and energy). If the Earth's renewable natural resources were sufficient for the needs of humanity in the first half of the twentieth century, after that perriod, in conditions of the accelerated industrialization and demographical explosion, the impact of human activity on the environment tends to spiral out of control. 
Food and energy in sufficient quantities are obtained by modifying classical technologies, whose side effect is the production of residues in worrying amounts that the accumulation trend to altered environmental factors.

Food increased demand led to increased acreage (by deforestation, fertilization of surface unproductive) having the side effects diminishing forest areas (less oxygen, disequilibrium in the hydrological regime), reduced areas for hydrographic protection (floods), changing the balance atmospheric moisture circulation of air currents. Increasing crop productivity was done by irrigation and chemical fertilization with effects in balance basin, soil pollution (pesticides remaining) and groundwater (inorganic nitrogen, pesticides). Farms and livestock produce large amounts of animal protein, but also large amounts of manure, with disastrous effects on surface waters (clogging algae).

Increased needs of industrial goods lead to higher energy demands (produced in the majority of non-renewable resources) and produce large amounts of waste (carbon dioxide, particulate matter, water and soil pollutants). Transport of goods/people produce large amounts of carbon dioxide (global warming) and nitrogen oxides (acid rain); also construction activity produces air dust and soil pollutants. Urban agglomerations produce large amounts of waste, both by domestic and industrial consumption.

Disequilibrium can lead to the strong worries on human survival and existence of life on our planet.

In these conditions have been adopted measures for restoring the balance of man/nature by reducing the impact of human activity (less polluting technologies, renewable energy, waste recycling)

Managing the environment is the responsibility of traders. This activity is based on obtaining reliable information on any kind of emissions and adoption of effective measures on reducing environmental impact. Any exceeding the legal limits lead to the imposition of sanctions (penalties or stopping/reducing traders activity) in order to resolve disequilibrium.

Monitoring of any kind of emissions is done through periodic evaluations of the results of laboratory tests. The resources required for the functioning of a laboratory consist of equipment/consumables and trained personnel. The costs are relatively high and not justified for any company that can call the specialized organizations. Based on the results of laboratory tests, the client organization establishes/not establish corrective action.

The degree of confidence in information provided by a laboratory depends on the professionalism and credentials acquired. An incorrect result may lead either to failure of corrections (and thus incurring sanctions from the authorities in finding exceeding emission limits) or unjustified investment.

Environmental legislation improves permanently by imposing reduced limits on 
emissions or the introduction of limits for new agents with environmental impact. Keep under control of environmental aspects is done by trained staff, who appreciate the impact of the information received and propose corrective actions. It also must implemented an effective management system on activities undertaken within company from receiving input data to verify the effectiveness of actions performed.

\section{EXPERIMENTS}

\section{Accreditation of testing laboratories and the degree of confidence in the test result.}

Accreditation of a laboratory by an internationally recognized body is a complex activity, conducted according to the requirements of referential valid worldwide (ISO/IEC 17025: 2005)[1]. Tests conducted by an accreditated laboratory are recognized international (through the mutual recognition of national accreditation bodies activities) and can not be contest legally. The accreditation consists of regular assessments (annual) of the laboratory activity general requirements of the management system and technical requirements (personnel training, calibration of critical equipment, use of reference materials, participation in activities external verification/inter-comparisons or internal / graphics results, etc.).

Case studies were conducted for two testing laboratories the first and third party (laboratories that check water quality and oil sludge); laboratories perform at the required tests for company outside the urban area.

\section{Certification of management systems}

Certification of management systems must be carried out by specialized organizations (accredited certification bodies), in accordance with referential international (ISO 14001: 2015 and/or ISO 9001: 2015) [2]; [3] and consists of periodic evaluations (annual) of how the client organization meets the requirements (receiving information, check them and shares effective procedure completed on the legal provisions). Implementing and cetification of an effectively system, guarantees minimizing environmental emissions of any kind, and reintroduction into the economic circuit of recoverable materials.

The case study was conducted cereal processing unit (extrusion and expansion) for furnace plant for semi-finished or finished products.

\section{RESULTS AND DISCUSSIONS}

\section{Resources needed and results of accreditation}

Resources needed for testing laboratory accreditation (eg. I - 10 environmental tests, 4 test responsibles; ex. II -20 environmental tests, 6 test responsibles) 


\begin{tabular}{|c|c|c|c|}
\hline No. & Held activity & Eg. I & Eg. II \\
\hline 1 & $\begin{array}{l}\text { Accreditation (initiation, } \\
\text { documentation analysis } \\
\text { assessment, decision) }\end{array}$ & 2500 & 3000 \\
\hline 2 & $\begin{array}{l}\text { Supervision (three annual } \\
\text { surveillance) }\end{array}$ & $3 \times 1400$ & $3 \times 1700$ \\
\hline \multicolumn{2}{|c|}{ Total costs } & 6700 & 7100 \\
\hline \multicolumn{2}{|c|}{ Costs/year (four years) } & 1675 & 1775 \\
\hline \multicolumn{4}{|c|}{ Table . 2 Indirect costs ( euro ) / year } \\
\hline No. & Held activity & Eg. I & Eg. II \\
\hline 1 & personal training & 100 & 150 \\
\hline 2 & interlaboratory tests & 300 & 400 \\
\hline 3 & $\begin{array}{l}\text { Critical } \\
\text { calibrations }\end{array}$ & 300 & 300 \\
\hline 4 & Reference materials & 300 & 500 \\
\hline 5 & Internal review activities & 100 & 100 \\
\hline \multicolumn{2}{|c|}{ Total costs } & 1100 & 1450 \\
\hline
\end{tabular}

Total accreditation/maintaining accreditation costs: $\quad I=2775$ euro II $=3250$ euro

\section{Accreditation results}

eg. I - about 30 tests/day, 12 euros/test;

eg. Il -about 50 tests/day, 12 euros/test.

Table 3. Eg I Laboratory

\begin{tabular}{|c|c|c|c|c|}
\hline No. & Specification & $\begin{array}{l}\text { Values / } \\
\text { year } \\
\text { (euro) }\end{array}$ & $\begin{array}{c}\text { Benefit } \\
15 \% \text { / } \\
\text { year } \\
\text { (euro) }\end{array}$ & $\begin{array}{c}\text { Staff } \\
\text { occupancy } \\
(\%)\end{array}$ \\
\hline 1 & $\begin{array}{l}\text { Cashing base year (before the } \\
\text { accreditation), direct labor and } \\
\text { others }\end{array}$ & 86.400 & 12960 & 75 \\
\hline 2 & $\begin{array}{l}\text { Cashing after the first year } \\
\text { accreditation (15\% increase }) \\
\text { own account and third parties }\end{array}$ & 98.900 & 14835 & 86 \\
\hline 3 & $\begin{array}{l}\text { Cashing second year after } \\
\text { accreditation and next (25\% } \\
\text { increase) own account and third } \\
\text { parties }\end{array}$ & 108.000 & 16200 & 94 \\
\hline
\end{tabular}




\begin{tabular}{|c|c|c|c|c|}
\hline No. & Specification & $\begin{array}{l}\text { Values / } \\
\text { year } \\
\text { (euro) }\end{array}$ & $\begin{array}{c}\text { Benefit } \\
15 \% \text { / } \\
\text { year } \\
\text { (euro) }\end{array}$ & $\begin{array}{c}\text { Staff } \\
\text { occupancy } \\
(\%)\end{array}$ \\
\hline 1 & $\begin{array}{l}\text { Cashing base year (before the } \\
\text { accreditation), direct labor and } \\
\text { others }\end{array}$ & 120.000 & 18000 & 75 \\
\hline \multirow[t]{2}{*}{2} & $\begin{array}{l}\text { Cashing after the first year } \\
\text { accreditation }(15 \% \text { increase })\end{array}$ & 138.000 & 20700 & 86 \\
\hline & own account and third parties & & & \\
\hline \multirow[t]{2}{*}{3} & Cashing second year after & 150.000 & 22500 & 94 \\
\hline & accreditation and next $(25 \%$ & & & \\
\hline
\end{tabular}

\section{Total additional costs / additional benefit}

Eg. I: in the first year after accreditation 2775/1875 and 2775/3240 in the second year and next years after accreditation

Ex. II: in the first year after accreditation 3250/2700 and 3250/4500 in the second year and next years after accreditation

In the two cases were not taken into account any non-accredited laboratories damage or penalty requested by customers in case of providing false readings (about 500 euro ( event)

\section{Necessary resources and resulting certification}

Ex III - cereal procesing unit, total staff 100 employees, expansion/extrusion

\section{Resources needed}

Direct costs: $\quad$ certification - 1200 euro

annual surveillance (2 surveillance) - $2 \times 600$ euro

total costs (three years) - 2400 euro, 800 euro/year

Indirect costs personal training - 100 euro / year

environmental tests (gas combustion) $4 \times 50$ euro -200 euro / year

Total cost $-€ 1100 /$ year

\section{Certification results}

Yield improved $7 \%$ of the drying plant that decrease energy costs by about 2000 euros / year

Total additional costs / profit extra 1100/2000 in the first year of certification. Were not taken into account any penalties to finding gas emissions and costs exceeding equipment wear in operating statement in adverse conditions. 


\section{CONCLUSIONS}

The costs of testing third party laboratories accreditation are fully recovered in the first two years by increasing the number of customers (increasing confidence in the quality of the test).

The costs of certification can be fully recouped in the first year, by monitoring parameters and implement corrective actions.

\section{ACKNOWLEDGEMENT}

SC ROMMAC TRADE SRL, grain processing company

URBAN SA , laboratory for analysis of drinking and waste water

WASTE LABORATORY SA , laboratory for enviromenthal tests

\section{REFERENCES}

[1] ISO/IEC 17025:2005 General requirements for the competence of testing and calibration laboratories

[2] ISO 14001:2015 Environmental management systems -- Requirements with guidance for use

[3] ISO 9001:2015 Quality management systems -- Requirements 